\title{
Rethinking Indian Diaspora: Conceptualizing Diasporic Consciousness
}

\author{
Prakash Chandra Pradhan \\ Professor, Department of English, Banaras Hindu University, Varanasi-221005. India. \\ Mail Id: prakashcpradhan@gmail.com | ORCID ID: 0000-0002-3002-4025
}

\begin{abstract}
Diaspora as a concept has drawn the attention of the scholars for a long time. In recent times, the meaning of the term has been rethought because the earlier meaning of the term associated with homelessness has been reviewed. In the past, the diasporic community were living in a foreign country due to the compulsion of their economic needs. The origin of Indian diaspora traces back to the indenture system introduced by the Imperial regime of Great Britain in the early part of 19th century. Migration to different parts of the world by Indians for trade and commerce, of course, traces back to much earlier in history. The old Indian Diasporas were longing to come back to their homeland because they felt that they were leading a life of deprivation and exploitation. However after independence, the new Diasporas have voluntarily chosen their condition of self-exile for a glamorous life in their chosen destinations. Often they also experience a sense of loss and anguish when they cherish the memory of their cultural roots. These new Diasporas aredifferentfrom the old as the latter long for intellectual freedom, secularism and liberty for their country. This paper is thereforean attempt to understand a perspective of the old and new Diasporas with reference to select theoretical formulations.
\end{abstract}

Keywords: Diaspora, Transnationalism, Postcolonialism, Nepantilism, Deterritorialization

\section{Introduction}

The term "diaspora" has its roots in the Greek words"dia (over)speiro (to sow)" meaning to scatter or disperse. It was first used for the Jews who were sent into exile after Nebuchadnezzar's conquest of Babylon. The Jews were wandering in exile without a homeland. Though the term refers to the physical dispersal of the Jews throughout the world, it also carries "religious, philosophical, political and eschatological connotations" because a special relationship is understood to exist between the land of Israel and the Jewish people (The Encyclopaedia Britannica). Thinking of this meaning, the South African freedom fighter Dr. Fatima Meer "abhorred the term diaspora" adding that it described overseas Indians as a people without a home. She said: "We 
Indian South Africans have had to struggle hard to claim our South Africanness, and that is something we jealously guard. We are not a diaspora of India" (Shubha Singh: 17). She uttered all these during the first Pravasi Bharatiya Divas in January 2003 distasting the use of the term to describe people of Indian descent. Of course, diaspora was once a term that referred primarily to the Jewish dispersion. It has, however, come to be used to refer to contemporary situations that involve the experiences of migration, expatriate workers, refugees, exiles, and ethnic communities. It indicates a distance and separation from a society of origin with which there is a continuous affinity. Diaspora is associated with minority and migrant populations that involve experiences of transnational identity. The term 'transnational' is also used in the diasporic sense to denote ethnic ties that cross national boundaries. Diasporas are shaped through migration along specific route and histories carrying collective memories and similar identity values. They retain their own distinctiveness in relation to their daily transactions to others around them.

The debate over the propriety of the term still continues in academic circles though diasporic studies has become the standard description for academic work on minorities living away from their ancestral homelands. Despite its close connection to the Jewish people and also to Israel, the term has come handy to denote to migrant communities around the world. In recent times, the term diaspora has been used to describe any minority community that can trace its origin from another land. This term has common usage in international political circles because the developed countries, which have been the receiving large scale migrants, formulate policies to integrate ethnic minorities in their social system. However, it still remains a problematic term especially in the countries that regard their migrant groups as outsiders. It is so, because it inevitably tends to draw comparisons with the Jewish diaspora, denoting at the same time a transnational motivation and linking it to a common religious, cultural, and political thought.

In the countries that are in the process of nation building like South Africa, any reference to transnational affinities with a lost homeland is suspected in the host country. The celebration of a migrant community is a modern concept of recent origin in western countries. In many countries migrants are still struggling for acceptance as full-fledged citizens of the adopted land and talking about diasporic loyalties raises suspicion as it can set them apart. But more and more countries are trying to use the influence of their successful migrant communities. Though purists may disapprove of the use of diaspora to describe overseas communities, the usage has come to stay till a new coinage is accepted. By the late 1980s a new age of Asian development had started with the new economic boom in Southeast Asia. The rapid development of the economies of Malaysia, Thailand and Indonesia was the contribution of their industrious Chinese communities. China's growing ties with America and the economic reforms in China under Deng Xiaoping brought a change in attitude towards communist China. Overseas Chinese enjoyed China's image of a powerful and influential state, which added respect for the homeland. China's nuclear capability, its independent stance and challenge to the West made the Chinese people proud. It does not mean that they are willing to return home, but the power and prestige strengthened the desire to 
maintain ties with China. However, in recent times, China has behaved inappropriately in respect of certain international issues for which its image has been tarnished.

Many countries have made efforts to channelize the energies of their overseas communities, but none have been so effectively used as the Jewish and Chinese Diasporas. The Chinese government has focused mainly on economic benefits of its diaspora, while the Jewish diaspora is focused on religious and political issues pertaining to Israel. The Jewish diaspora and its organisations promote the interests of the state of Israel through its connections to international community. It is a significantly prosperous community around the world. It exhibits much influence in American politics and is an important factor in American policies towards West Asia and Israel. Indians in the US have tried to connect themselves through Jewish lobbying groups in their efforts to reach American politicians in the US congress. Governments have offered a large number of facilities to keep in touch with the Diasporas. Regular conferences, committees to advise parliament, even nominated seats in the legislature, active encouragement to visit the homeland have kept the migrant communities connected. More and more countries are trying to reach out to prosperous emigrants for a variety of reasons that include forcing the influence, enhancing a global presence, providing access to foreign investment.

Largescale migration from Asia began when Europe's imperial powers established colonies in the New World to meet the demand for tropical commodities like rubber, sugarcane, tea, and coffee in Europe. The colonies' initial need for labour at the plantations, the tin and the goldmines was met through slaves. But when slavery was abolished throughout the British Empire in 1833, the plantation owners needed replacements for the African slave labour. A substitute work force was sought in Indian and Chinese emigrant workers on indenture. Over one and a half million Indians went overseas to earn a living in the $19^{\text {th }}$ and the early part of the $2^{\text {th }}$ century to Burma, Malaya, Africa, the Caribbean and the Pacific islands. By 1938, the overseas Indians spread over a belt which ran around the Equator from the North Atlantic over the Indian Ocean to the South Pacific. Since the Indian community abroad grew to over 20 million with people of Indian descent spread throughout the world, with a considerable presence in about 110 countries. The overseas Indian community spread widely, and after the Jewish and the Chinese, it is the largest diaspora. It is a heterogeneous group but is formed of numerous segments that correspond to the time of migration, the place of origin in India and the country of settlement. Educational levels, class background, age and gender are also important factors to make other differences. For about two hundred years, migrants went to Malaysia, Sri Lanka and other South East Asian countries as indentured workers. They went to the colonies to work in Trinidad and Tobago, Mauritius, Surinam, South Africa, and Fiji. Even before the 19th century, there had also been migration. Migration is certainly an important part of history and through the ages, people have travelled faraway to find land, food, and work. The myth of Indians as a traditionally home sick people is rather unacceptable because in reality the sea-faring coastal regions have a tradition of mobility and maritime history. 
Growing migration of human populations across the geographical, cultural and political frontiers in recent times has impacted in increase of critical theories on diaspora. Diasporic consciousness is a very important feature in the writings of the writers staying away from their native land. These writers are often preoccupied with the feelings of dislocation, exploitation, nostalgia and racial bias. Their writings also relate to hybridity, marginalisation and protest against injustice. In intellectual circles, two types of diasporas are much discussed.

In its old sense, the term signifies to the Jewish living outside Palestine or modern Israel. The contextual significance of the term refers to "a dispersion or migration of people coming from the same country or having a common culture" (New Penguin English Dictionary 385). In a wider perspective the term connotes the evolution of all human civilization and culture. The primitive human beings were first located in Africa. However, they later on spread over to several places of human settlements and societies all over the world thereby rendering the human condition as diasporic. In reference to the Indian poetic tradition and Judeo-Christian tradition, we understand that the human situation is diasporic. Separation of human from God is also a diasporic situation. In the Indian context, we know that Atma (soul) and Brahma (the Great Soul) are also separated when the soul, bound to a body, takes birth on the earth. The diasporic situation has therefore a philosophical significance. The term's meaning relating to its Greek origin is based on a political connotation meaning "voluntary or forcible movements of the people from their homelands into new regions" (Ashcroft et al 1998:70). Bill Aschroft, Gareth Griffiths, and Helen Tiffin carried on two projects on colonialism and Imperialism which are related to radical diasporic movements (Ashcroft et al 1998:69). They found that millions of Europeans and the natives were dislocated at different regions. These scholars believe in human condition as diasporic from historical perspective. The indenture system after the abolition of slavery contributed to diasporic condition of a large number of people from the colonised Asian counties to different parts of the British Empire:

This involved transporting, under indenture agreements, large populations of poor agricultural labourers from... areas such as India and China, to areas where they were needed to service plantations. The practices of slavery and indenture thus resulted in worldwide diasporas. ( $\underline{\text { Ashcroft }}$ et al $1998: 69$ )

This historical incident resulted in substantial increase of indentured workers known as Girmitiyas in the West Indies, Malaya, Fiji, Mauritius, and the colonies of the East and South Africa. Gandhiji as a girmit himself mobilised the disparate and despair-ridden girmitiyas in South Africa for about 21 years from 1893 to 1914. Amidst the hostile circumstances of racism, colonialism and other forms of oppression, his efforts to organise these girmitiyas as a politically conscious people are noteworthy. He saw that the Indians, both indentured and freed, suffered indignities of racial abuse of all kinds. Sharing their common feelings of alienation, nostalgia, possession of mythical memories, displacement and racism, he could mobilize them to strive for their upliftment. 
The diasporic consciousness involves a number of feelings and conditions, namely alienation, dispersal, longing for the ancestral land, double-identification with homeland and the country of adoption, identity crisis, remembrance of myths, legends and cultural tradition related to homeland, protest against discrimination of all sorts in a new land. The metaphor of imaginary homelands sums up the conditions of the diasporic communities. Very often the condition of diaspora is compared to the "condition of the idea of Indian mythical king Trishanku's "in-between space". The Des-pardes dialectic is also crucial to understand diasporic consciousness.

In South Africa, Gandhiji fought for the cause of the marginalized who were subject to racial hatred and exploitation. His theory of freedom struggle to liberate the downtrodden is based on truth and non-violence (Satyagrah and Ahimsa) which are his weapons of spiritual force. Since diasporic discourse is largely political, based on power relationship, Gandhiji therefore never wanted a separate homeland for the Indians in South Africa. He rather wished a mutually shared socio-cultural space in South Africa. The hybrid condition should have to be used for political empowerment of the most deprived diasporic subjects. In his Autobiography, Gandhiji seems to be a writer of diasporic consciousness. There has been a great focus on English writers of Indian origin, namely Salman Rushdie, V.S.Naipaul, Nirad Chaudhuri, Amitav Ghosh and many others. Their works portray the complex discursive issues of multiculturalism, diasporic hybrid identities, national imaginary, dislocation and exile. Major diasporic theoretical formulations revolve round Homi Bhabha, Stuart Hall, Gayatri Spivak, Robert Young and others. These writers/theorists dominate in the areas of studies such as postcolonialism, postmodernism, cultural studies, new historicism and diasporic studies.

The notion of diaspora is therefore a contested field of study. Any conceptualization of the term leads to debatable discussion. Summating theoretical formulations on diaspora seem to be impossible. Any theory of diaspora should not be author-centred. Stuart Hall writes: "In an era of globalization, we are all becoming diasporic" (1992:402). Salman Rushdie, Edward Said and George Steiner also make such claims. Stuart Hall's claim foregrounds the contemporary world reality in the transnational moment. It also evidences exultant claims made in respect of philosophical diasporization affected by the processes of globalization. Diaspora has a semantic domain, stretched in various directions resulting in different meanings: exile, refugee, immigrant, migrant, nomad, privileged Non-Resident Indians (NRI), PIO (person of Indian origin). It also refers to many types of diaspora: classical diaspora, first, second and third generation diasporas, trading diaspora, mobilized diaspora, catastrophic diaspora, victim diaspora and so on. Many thinkers have laid emphasis on the need to regulate the spacious boundaries of diaspora through its rigorous conceptualization. Jana Evans Braziel and Anita Mannur are critical of the reckless use of the term diaspora in their introduction of the book Theorizing Diaspora: "... [T] he term 'diaspora' risks losing specificity and critical merit if it is deemed to speak for all movements and migrations between nations, within nations, between cities within cities adinfinitum" (2003:07). They argue that the term diaspora should be theorized so that it can be employed as a useful method of study. 
The term diaspora has flexible meaning for which it poses certain problems in its theorization. Although theories are often generalizations, a theory of diaspora is often useful for bringing in a perspective to it. A number of theorists have contributed to the theorization of diaspora through their meaningful formulations. The following theorists are noteworthy: Edward Said, Homi K Bhabha, Gayatri Chakravorty Spivak, Stuart Hall, Paul Gilroy, R.Radhakrishnan, Sura P Rath, Vijay Mishra, Robin Cohen and N. Jayaramana. They have engaged in discussing the conflicted but interrelated territories of home-location, nation-postnation, inside-outside, citizen-stranger, purehybrid, roots-routes, centre-periphery, sameness-difference and subject-object which criss-cross and clash. It has resulted in diaspora searching for its multi-referential signification. These binaries bring with them traces of their past relations and interactions also. Their affiliations with poststructuralism, postmodernism and postcolonialism add still greater complexity to the concept of diaspora. This complexity of the term is responsible because it has been appropriated in a variety of disciplines and discourses. This complexity might bring about disintegration of "dispersal of diaspora and diasporization of diaspora". The comments of Rogers Brubaker are relevant to quote here. He argues that the term has proliferated, and its meaning has been stretched to accommodate the various intellectual, cultural and political agendas in the service of which it has been enlisted. This has resulted in what one might call a diaspora diaspora, a dispersion of the meanings of the term in semantic, conceptual and disciplinary space (2005: 1-19) .

The earliest studies treated Diasporas as bounded entities. William Safran defined the term in an ideal way. James Clifford illustrates Safran's model. He enlists six main features of Safran's conceptualisation of expatriate minority status of diaspora: "a history of dispersal, myths/memories of the homeland, alienation in the host (bad host?) country, desire for eventual return, ongoing support of the homeland, and a collective identity importantly defined by this

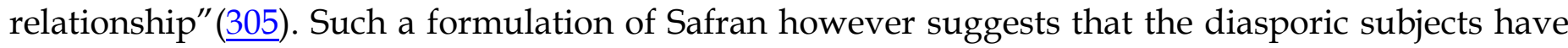
homogenous and collective identities bound together by shared feelings of alienation and having a very strong nostalgic longing for the place of origin. Clifford is not happy with an ideal type of conceptualisation because the pure forms are "ambivalent, even embattled over basic features" (1994:306). Alluding to Jewish diaspora, the discussions drew on a conceptual homeland. Grounding himself in a nationalist space, Makarand Paranjape has also a similar notion. He thinks that the Diasporas must involve in a cross-cultural passage to have a unique diasporic consciousness. He pleads that "there has to be a source country and a target country, a source culture and a target culture, a source language and a target language, a source religion and a target religion, and so on. Also, the crossing must be forced, not voluntary; otherwise, the passage will only amount to an enactment of desire-fulfilment. Or, even if voluntary, the passage must involve some significant tension between the source and target cultures" (2001:16). However, such specific ways of definition enlisting characteristic features seem to be simplistic. Counterpoising such schematic theories, some recent thinkers take rather different stances. Homi Bhabha, Stuart Hall, Avtar Brah, R. Radhakrishnan and others draw on such terms as hybridity, palimpsest identities, 
displacement, decentrement difference and alterity which have strong affiliations with poststructuralism, postmodernism and postcolonialism.

Homi K. Bhabha talks about hybrid identity of diaspora who are:

Gatheringsof exilesand emigres and refugees; gathering on the edge of foreign cultures; gathering at the frontiers; gatherings in the ghettos or cafes of city centres;gathering inthe half-life, half-light of foreign tongues or in the uncanny fluency of another's language gatherings the signs of approval and acceptance, degrees, discourses, disciplines; gathering the memories of underdevelopment of other worlds lived retroactively; gathering the past in a ritual of revival; gathering the present.(1994:139)

The Diasporas are hyphenated and hybrid subjects because they inhabit liminal spaces, and they have intercultural experiences. However, this hybridity is not natural and organic since there is no blending and reconciliation of codes of culture, race, colour, ethnicity and gender. This hybridity is self-reflexive and is the result of a conscious negotiation with its informing elements. The hybrid existence of the Diasporas draws attention to the fluid identities which are continuously reframed in ongoing negotiation with the changing political environment.

Stuart Hall argues that the diaspora experience "is defined, not by essence or purity, but by recognition of a necessary heterogeneity and diversity, by a conception of identity which lives with and through, not despite, difference; by hybridity and diaspora identities are constantly producing and reproducing themselves anew, through transformation and difference" (1993:402). This indeterminacy of the fluid diasporic identities, in the words of Jacqueline Lo, disrupts "homology between cultural, racial and national identity". The hyphen also draws attention towards the suppressed histories of cross-cultural and cross-racial relations. This self-reflexive hybridity, in Bhabha's words, an "insurgent act of cultural translation" (1994:7) is rife with the subversive potential to unsettle hegemonic relations as it focuses on processes of negotiation and contestation between cultures. Hybridity and hyphenation, according to Jacqueline Lo, "offer an alternative organising category for a new politics of representation which is informed by an awareness of diaspora and its contradictory, ambivalent and generative potential". Bhabha therefore thinks that the in-between space occupied by the diasporic subject has creative possibilities: “... (I)t is the space of intervention emerging in the cultural interstices that introduces creative intervention into existence" (1994:7). Like Bhabha, Salman Rushdie and Edward Said also visualize creative potentialities in the exilic condition. For Avtar Brah the "diaspora space is the intersectionality of diaspora border, and dislocation as a point of confluence of economic, political, cultural and psychic processes. It is where multiple subject positions are juxtaposed, contested, proclaimed or disavowed" (2002:208). He therefore argues that diaspora space is a highly contested site.

An important label, namely eclectic hybridity, is necessary to be discussed as it refers to the fusion of music, cuisines and cultures. It is a postmodern pastiche culture containing variety of elements, and also refers to variety in influence. This category of hybridity tends to empty the term hybridity 
of its political content and historical specificity and exposes it to the charge of blocking the pain of living in diaspora. For suppressing the suffering of the exile in their celebration of cultural hybridity and the third space, Aizaz Ahmed, Benita Parry and Lawrence Phillips have critiqued Bhabha, Rushdie and Said. Nikos Papastergiadis argues for "a sense of Diasporas that says more about a sensibility towards cultural transformation than designating a place of arrival or rebirth" (1998: xii). Intentional hybridity as a condition of conscious negotiation of intersecting cultures means that we cannot see Diasporasin integrated perspective. Considered as a sensibility towards cultural transformation diaspora can be regarded as a practice since Brubaker's analysis has been to desubstantialize it by treating it as a category of practice rather than as a restricted group. We can therefore talk about the diasporic project in terms of destabilizing generalized claims made on behalf of nation, culture, race, gender and so on.

The hyphenateddiasporic subject embodies difference relationally and non-hierarchically. R. Radhakrishnan therefore says:

Peoples and cultures are different; and the all-important issue is how to receive and practice difference relationally and non-hierarchically; in other words, how to create a society that will not evaluate some differences more positively than others. Furthermore, practising or embodying difference (a great example is the project of dwelling rigorously and passionately in the hyphen within succumbing to total integration on either side of ethnic hyphenation, i.e. sustaining difference along multiple axis without totalization) does not have to take the form of an ideologically reductive and non-porous identity politics .... Differences and heterogeneities can be practiced openly, relationally, and as invitations to a rich and ongoing heteroglossia, rather than be primed as a raw material for some grand unification or cultivated as hotbeds of separatist thought. (2004:65)

Gloria Anzaldua, a Mexican-American, in her bookBorderlands/ LaFrontera: TheNewMestiza(1987) talks about the emergence of a new consciousness(mestizaconsciousness). Borderlands is an example of the performativity of the hyphenated diasporic subjectivity and the diasporic epistemology which "locates itself squarely in the realm of hybrid, in the domain of cross-cultural and contaminated social and cultural regimes" (Vijay Mishra 1996:71). Anzaldua writes:

In a constant state of mental nepantilism, an Aztec word meaning torn between ways, lamestiza is a product of the transfer of the cultural and spiritual values of one group to another. Being tri-cultural, monolingual, bilingual or multilingual, speaking a patois, and in a state of perpetual transition, the mestiza faces the dilemma of the mixed breed: which collectively does the daughter of a dark-skinned mother listen to? (1987:78)

Anzaldua faces the ambivalence and lives the pain of juggling not two but three cultures: "Cradled in one culture, sandwiched between two cultures, straddling all three cultures and their value systems, la mestiza undergoes a struggle of flesh, a struggle of borders, an inner war" (1987:78). The 
new mestiza has to develop tolerance for contradictions and ambiguities and in doing so she acquires a plural personality. This flexibility opens up new creative possibilities for her:

The focal point or fulcrum, that juncture where the mestiza stands, is where phenomena tend to collide. It is where the possibility of uniting all that is separate occurs. This assembly is not one where severed or separated pieces merely come together. Nor is it a balancing of opposing powers. In attempting to work out a synthesis, the self has added a third element which is greater than the sum of its several parts. The third element is a new consciousness a mestiza consciousness - and though it is a source of intense pain, its energy comes from continual creative motion that keeps breaking down the unitary aspect of each new paradigm". (1987:79)

Anzaldua interrogates her hyphenated identity and does not privilege either side of the hyphen. She questions both the sides of her ethnic hyphenation: "I am an act of kneading, of uniting and joining that not only has produced both a creature of darkness and a creature of light, but also a creature that questions the definition of light and dark and gives them new meanings"( 1987:80-81). Such reflexive and radical hybridity retains the oppositional frame of reference diaspora evokes.

The theories discussed in the preceding pages elucidate that Diasporas are regarded as the "deterritorialized" other of the territorialised nation-state which is considered as a homogenous unity though in reality it is heterogeneous. Since there is always a haunting desire for the homeland, the Diasporas are therefore affected by a diasporic consciousness. Though Rushdie and Bharati Mukherjee talk about multiculturalism and assimilation respectively, Avtar Brah however talks about the idea of homing desire: "The concept of diaspora places the discourse of home and dispersion in creative tension, inscribing a homing desire while simultaneously critiquing discourses of fixed origins" (2002:192-193). Homing desire is not the same as desire for homeland. It is rather a desire for creating a home in the host culture. The old Diasporas cannot accept such homing desire. They would rather prefer to have a constant desire for their homeland as they are constantly affected by a diasporic consciousness.

\section{References}

Ahmad, Aijaz. In Theory: Classes, Nations, Literature. New Delhi: Oxford,1992.

Anzaldua, Gloria. Borderlands/La Frontera: The New Mestiza, 1987

Ashcroft, Bill, Gareth Griffiths, and Helen Tiffin. Key Concepts in Postcolonial Studies. London:

Routledge, 1999.

Bhabha, Homi K. The Location of Culture. London: Routledge, 1994.

Brah, Avtar. Cartographies of Diaspora: Contesting Identities.(1996). London: Routledge, (rpt.)2002. 
Brazel, Jana Evans and Anita Mannur, ed. Theorizing Diaspora: A Reader. Oxford: U. K.Blackwell Publishing,2003.

Brubaker, Rogers. “The Diaspora Diaspora”.Ethnic and Racial Studies,2005, vol.28.1 .1-19.

Christian, Laura and Parry, Benita, eds.Postcolonial Theory and Criticism. London:D.S. Brewer,2000.

Clifford, James. “Diasporas". Cultural Anthropology, Vol. 9,3,1994.

Gandhi, Mahatma. The Story of My Experiments with Truth: An Autobiography. Fingerprints, 2009.

Hall, Stuart. "Cultural Identity and Diaspora". Colonial Discourse andPostcolonial Theory, ed. Patrick Williams and Laura Christman. London: Longman, 1993.

Lo, Jaqueline. “BeyondHappy Hybridity: Performing Asian-Australian Identities." Alter/Asians,eds.len Ang et al. Pluto Press,2000.152-168.

Mishra, Sudesh. "From Sugar to Masala:Writing by the Indian Diaspra". An IllustratedHistory of Indian Literature in English, ed. Aravind Krishna Mehrotra. Delhi:Permanent Black, 2003.287-288.

Mishra, Vijay. “New Lamps for Old: Diasporas Migrancy Border". Interrogating Postcolonialism: Theory, Text and Contex, eds. Harish Trivedi and Meenakshi Mukherjee. rpt.1996. Shimla: India Institute of Advanced Studies,.rpt. 2000.67-86.

Nandan, Satendra. "The DiasporicConsciousness: From Biswas to Biswaghat”. InterrogatingPostcolonialism: Theory, Text and Context, eds. Harish Trivedi and Meenakshi Mukherjee 1996. Shimla: India Institute of Advanced Studies,rpt. 2000.49-66.

Papastergiadis, Nikos. Dialogues in the Diasporas: Essays and Conversations on Cultural Identity.1997. London: Rivers Oram Press, 1998.

Paranjape, Makarand. In Diaspora. New Delhi: Indialog Publications, 2001.

Radhakrishnan,R. Theory in an Uneven World.(2003). Malden: Blackwell Publishing, (rpt.)2004.

Rushdie, Salman. Imaginary Homelands: Essays andCriticism. 1991. London: VintageBooks,2010 Safran, William. “Diasporas in Modern Societies: Myths of Homeland and Return”. Diaspora: A Journal of Transnational Studies.1.1 (1991):83-99.

Singh, Subha. Overseas Indians: The Global Family. Delhi: Shipra Publications, 2005.

The New Penguin English Dictionary. New Delhi: Penguin India,2000.

The Encyclopaedia Britanica

Prakash Chandra Pradhan is Professor of English, Banaras Hindu University, Varanasi, India. He has published 5 books, 63 research papers and reviews in the international and National journals, 26 articles in magazines, and edited many research journals, books, and magazines. Professor Pradhan has guided a number of research scholars; presented papers; acted as resource person; chaired sessions; and organized seminars, conferences and Refresher courses. 